Jane M. Henderson MD FRCPC, Desmond G. Spence MB FRCPC, William N. Clarke MD FRCSC FACS, Gary G. Bonn MD CSPQ FRCSC FACS, Leon P. Noel MD CSPQ FRCS

\title{
Sodium citrate in paediatric outpatients
}

To determine whether the gastric content $\mathrm{pH}$ of paediatric patients could be raised in an effort to decrease post-aspiration morbidity and mortality, the antacid sodium citrate 10.4 $\left.\mathrm{ml} \cdot \mathrm{kg}^{-1}\right)$ was given preoperatively to 25 patients aged 1 to 14 $(6.0 \pm 3.5$, mean $\pm S D)$ years. Their gastric content $p H$ was measured following induction of anaesthesia. These values were compared to thase abrained from a control group $(n=20)$ ranging in age from seven months to nine $(3.3 \pm 2.7)$ years. $A$ gastric content $p H$ value of greater than 2.5 was measured in 23 of the 25 patients who received sodium citrate. There were only two patients in the control group with a gastric content $\mathrm{pH}$ greater than 2.5, $p<0.001$, Fisher exact test. Only one child refused to take the medication. The administration of sodium cirrore appears to be an effective method of raising the gastric content $\mathrm{pH}$ in paediatric patients.

Aspiration of foreign material into the lungs during anaesthesia, although rare, can have devastating sequelae. Aspiration was the cause of death in 26 per cent of cases in a survey of paediatric anaesthesia mortality. ${ }^{1}$ In addition, the incidence of aspiration during anaesthesia appears to be higher for the paediatric age group compared to adults. ${ }^{2}$

Nearly all paediatric patients (3-17 years of age) present for surgery with a gastric content $\mathrm{pH}$ of $<2.5$, whereas 24 to 75 per cent of adults will have a $\mathrm{pH}$ this low. ${ }^{3}$

Early work by Mendelson ${ }^{4}$ and Teabeaut ${ }^{5}$ demonstrated that as the $\mathrm{pH}$ of gastric fluid instilled in the trachea decreased below 2.5 , the degree of lung damage increased.

\section{Key words}

ANAESTHESIA: paediatric; COMPLICATIONS: gastric acid aspiration prophylaxis; GASTRIC ANTACIDS: sodium citrate.

From the Department of Anaesthesia (JMH, DGS) and the Department of Uphthalmology, Children's Hospital of Eastern Ontario, Ottawa, Ontario.

Address correspondence to: Dr. Desmond G. Spence, Department of Anaesthesia, Children's Hospital of Eastem Ontario, 401 Smyth Road, Ottawa, Ontario K1H 8Ll.
When the $\mathrm{pH}$ was greater than 2.5 the effect on the lungs was no worse than that following the administration of an equivalent volume of saline.

Many pharmacologic measures have been employed to alter the characteristics of gastric contents preoperatively. Sodium citrate, a non-particulate antacid, has emerged as an effective and safe method of raising gastric $\mathrm{pH}^{6}{ }^{6}$ and is often used routinely in obstetrical anaesthesia. Its use in paediatric anaesthesia has not been reported. We studied a group of paediatric surgical outpatients to determine the effectiveness of sodium citrate in raising the gastric content $\mathrm{pH}$ preoperatively

\section{Methods}

Institutional approval was obtained for the study and the parent of each child gave an informed consent. We studied 52 outpaticnts, ASA physical status I, 7 months to 14 years of age, who were scheduled for ophthalmologic procedures.

The patients were randomly assigned to two groups. Patients in Group 1 were given sodium citrate, 0.4 $\mathrm{ml} \cdot \mathrm{kg}^{-1}$, prepared in a $0.3 \mathrm{M}$ solution by the hospital pharmacy. The medication was given in the Surgical Day Care admitting area when the patients were called to the operating room. Group 2 received no antacid. No other premedication was given. Anaesthesia was induced either intravenously or with inhalational agents, as determined by the attending anaesthetist. Intubation was facilitated by intravenous succinylcholine $1.0 \mathrm{mg} \cdot \mathrm{kg}^{-1}$ preceded by atropine $0.02 \mathrm{mg} \mathrm{kg}^{-1}$. Immediately following tracheal intubation, a gastric tube was passed orally and its position in the stomach verified by insufflating air and auscultating over the abdomen. Stomach contents were aspirated by repeated suctioning in the supine and lateral positions. The volume was recorded and the $\mathrm{pH}$ measured using a Fisher Acumet $\mathrm{pH}$ meter.

Comparisons between groups were made using Student's t test for unpaired data. The patients within each group were divided into those with gastric content $\mathrm{pH}$ values $<$ or $\geq 2.5$. These data were analysed using the Fisher exact test. To detect whether gastric content $\mathrm{pH}$ was related to either age or weight, Pearson's coefficient of correlation was determined. A p value $<0.05$ was accepted as significant. 
TABLE 1 Patient characteristics, fasting period and gastric content volume and $\mathrm{pH}$ (mean \pm SD)

\begin{tabular}{|c|c|c|c|c|c|c|}
\hline & $N$ & $\begin{array}{l}\text { Age } \\
\text { (years) }\end{array}$ & $\begin{array}{l}\text { Weight } \\
(\mathrm{kg})\end{array}$ & $\begin{array}{l}\text { Fasting } \\
\text { period } \\
\text { (hours) }\end{array}$ & $\begin{array}{l}\text { Volurne } \\
\left(m g \cdot k g^{-i}\right)\end{array}$ & $\begin{array}{l}\text { Gastric } \\
\mathrm{pH}\end{array}$ \\
\hline $\begin{array}{l}\text { Group l } \\
\text { (Sodium citrate } \\
0.4 \mathrm{ml} \cdot \mathrm{kg}^{-1} \text { ) }\end{array}$ & 25 & $6.0 \pm 3.5^{*}$ & $23.9 \pm 11.5^{*}$ & $12.5 \pm 2.6$ & $0.8 \pm 1.1$ & $5.0 \pm 1.2^{*}$ \\
\hline $\begin{array}{l}\text { Group } 2 \\
\text { (control) }\end{array}$ & 20 & $3.3 \pm 2.7$ & $15.5 \pm 7.5$ & $11.4 \pm 3.0$ & $0.4 \pm 0.3$ & $2.0 \pm 0.6$ \\
\hline
\end{tabular}

$*_{p}<0.05$ compared to control ( $\mathrm{t}$ test).

\section{Results}

One child refused to take the medication, and we were unable to pass the gastric tubc in six paticnts in the control group. Data from these seven patients were excluded from the statistical analysis.

There was a significant difference in the gastric content $\mathrm{pH}$ values, ages and weights between the groups (Table I). There was no difference in fasting periods or gastric volumes. The sodium citrate was administered $13.8 \pm 6.6$ (mean $\pm S D$ ) minutes before the gastric tube was passed and the fluid aspirated. The number of patients in Group 1. (sodium citratc) who had a gastric content $\mathrm{pH} \geq 2.5$ was significantly greater than Group 2 (Table II). No significant correlation was found between $\mathrm{pH}$ and age (for Group 1, $r=0.10$ and the SEE (standard error of the estimate) $=1.18$, and for Group 2, $r=0.07$ and the $\mathrm{SEE}=0.64$ ) or between $\mathrm{pH}$ and weight (for Group 1 , $r=0.12$ and $S E E=1.17$, and for Group $2, r=0.07$ and the $\mathrm{SEE}=0.64$ ).

\section{Discussion}

Almost all children presenting for outpatient surgery who did not receive antacid had a gastric content $\mathrm{pH}<2.5$, a value generally accepted as the level below which significant lung injury occurs in the event of aspiration. 4,5 This is corroborated by earlier studies where up to 96 per cent of paediatric patients were found to have a gastric $\mathrm{pH}<2.5$. $^{3}$

There are a number of manoeuvres described as being protective against regurgitation in those patients at risk. These include a preoperative fasting period, awake intuba-

TABLE II pH results

\begin{tabular}{llll}
\hline & $\begin{array}{l}\text { Sodium } \\
\text { citrate }\end{array}$ & Coniroi & $\begin{array}{l}\text { Total } \\
\text { patients }\end{array}$ \\
\hline $\mathrm{pH}<2.5$ & $2^{*}$ & 18 & 20 \\
$\mathrm{pH} \geq 2.5$ & $23^{*}$ & 2 & 25 \\
Tọtal patients & 25 & 20 & 45 \\
\hline
\end{tabular}

$*_{p}<0.001$ compared to control (Fisher exact text). tion, rapid sequence induction and intubation using Sellick's manoeuvre until the airway is secured, awake extubation, and pharmacologic measures to alter gastric $\mathrm{pH}$ andior volume.

Of these manoeuvres, a fasting period does not necessarily ensure the presence of an empty stomach. Most of the children in this study had gastric volumes greater than $0.4 \mathrm{ml} \cdot \mathrm{kg}^{-1}$ and although a statistically significant difference was not detected, the children who received sodium citrate tended to have larger volumes than those in the control group. The volume of gastric contents may be underestimated by the technique of measurement used in this study. Studies in animals demonstrated that fluid in volumes greater than $0.4 \mathrm{ml} \cdot \mathrm{kg}^{-1}$ instilled in the trachea can cause permanent lung damage, as compared to little or no damage if the volume is smaller. ${ }^{7}$

The second manoeuvte, intubation, may not provide adequate protection against aspiration. Roy ${ }^{8}$ reported a case of aspiration of gastric material around an uncuffed endotracheal tube, which occurred in an eight-year-old intraoperatively. In a study of intubated children in an ICU, the incidence of aspiration of dye around uncuffed endotracheal tubes was 77 per cent. ${ }^{9}$

Finally, pharmacologic methods of altering gastric $\mathrm{pH}$ and/or volume include the use of $\mathrm{H}_{2}$ receptor antagonists, metoclopromide and antacids. Antacids, especially the non-particulate sodium citrate, have been used safely in obstetrical anaesthesia for a number of years. Sodium citrate has been shown to be as effective as cimetidine in raising gastric content $\mathrm{pH}$ preoperatively in patients aged 19 to 70 years $^{10}$ and has also been demonstrated to be safer than particulate antacids in the event of aspiration. When sodium citrate itself was aspirated by animals it caused only transient hypoxia ${ }^{11}$ compared to the aspiration of particulate antacids which produced chronic pulmonary granulation. ${ }^{12}$

We selected this dose of sodium citrate $\left(0.4 \mathrm{ml} \cdot \mathrm{kg}^{-1}\right)$, because the usual dose of sodium citrate given to adult patients is $30 \mathrm{ml}$ of $0.3 \mathrm{M}$ solution. This would indicate that $0.4 \mathrm{ml} \cdot \mathrm{kg}^{-1} \mathrm{might}$ be an appropriate paediatric dose, 
assuming a standard adult weight of $70 \mathrm{~kg}$. The sodium citrate was accepted well by the age group studied, with only one child refusing to take the medication. In the present study 92 per cent of the patients who received this dose had a gastric content $\mathrm{pH} \geq 2.5$.

We found that there was no significant correlation between patient age and weight and the gastric content $\mathrm{pH}$. The relationship of gastric content $\mathrm{pH}$ to age in paediatric patients (excluding neonates) has not been reported. Therefore, it is reasonable to assume that the observed difference in gastric content $\mathrm{pH}$ values was due to the administration of sodium citrate and not to a difference in age or weight between the groups.

Difficulty was encountered in passing the gastric tube in six patients, all from the control group. These patients ranged from one to seven years of age and all were given a similar anaesthetic. Multiple attempts were made using various-sized gastric tubes, but they appeared to be beld up in the oesophagus, perhaps in the region of the gastro-oesophageal junction.

In conclusion, nearly all patients who did not receive sodium citrate had a gastric content $\mathrm{pH}<2.5$. Sodium citrate was readily accepted by this paediatric age group and raised the gastric content $\mathrm{pH}$ of over 90 per cent of patients to a value greater than 2.5 . It is a simple and effective method of altering gastric content $\mathrm{pH}$ and should be considered as one manoeuvre to reduce post-aspiration morbidity and mortality.

\section{Acknowledgements}

The authors would like to thank Dr. Gary Johnson for his advice and Ms. Norma Padoin for the manuscript preparation.

\section{References}

I Graff TD, Phillips OC, Benson DW, Kelley E. Baltimore ancsthesia study committee: factors in pediatric anesthesia mortality. Anesth Analg 1964; 43: 407-14.

2 Olsson GL, Hallen B. Hambraeus-Jonzon K. Aspiration during anaesthesia: a computer-aided study of 185,358 anaesthetics. Acta Anaesthesiol Scand 1986; 30: 84-92.

3 Coté CJ, Goudsouzian NG, Liu LM, Dedrick DF, Szyfelbein SK. Assessment of risk factors related to the acid aspiration syndrome in pediatric patients-gastric $\mathrm{pH}$ and residual volume. Anesthesiology 1982; 56: 70-2.

4 Mendelson $C L$. The aspiration of stomach contents into the lungs during obstetric anesthesia. Am J Obstet Gynecol 1946; 52: 191-205.

5 Teabeaut JR. Aspiration of gastric contents; an experimental study. Am J Pathol 1952; 28:51-67.

6 Gibbs $C P$, Spohr $L, S c h m i d t D$. The effectiveness of sodium citrate as an antacid. Anesthesiology 1982; 57 : 44-6.
7 Raberts $K B$, Shirley $M A$. Reducing the risk of acid aspiration during cesarean section. Anesth Analg 1974; 53 : 859-68.

8 Roy $W L$. Intratoperative aspiration in a paediatric patient. Can Anaesth Soc J 1985; 32: 639-41.

9 Browning $D H$, Graves SA. Incidence of aspiration with endotracheal tubes in children. J Pediatr 1983; 102: 582-4.

10 Foulkes $E$, Jenkins $L C$. A comparative evaluation of cimetidine and sodium citrate to decrease gastric acidity: effectiveness at the time of induction of anacsthesia. Can Anaesth Soc J 1981; 28: 29-32.

II Gibbs CP. Hempling RE, Wynne JW. Antacid pulmonary aspiration (Abstract). Ancsthcsiology 1979; 51: $\mathbf{S 2 9 0 .}$

12 Gibbs CP, Sctwartz D., Wynne JW, Hood Cl, Kuck EII. Antacid pulmonary aspiration in the dog. Anesthesiology 1979; 51 : 380-5.

\section{Résumé}

Afin de déterminer s'il étail possible d'élever le $p H$ du contenu gastrique chez des enfants pour tenter de diminuer la morbidité et la mortalité post-aspiration, on a donné $0.4 \mathrm{ml} \cdot \mathrm{kg}^{-1}$ de l'antacide citrate de sodium, en période préopératoire, à 25 patients âgés de là 14 (6.0 \pm 3.5 , moyenme $\pm S D$ ) ans. Le pH du contenu gastrique a été mesuré à la suite de l'induction de l'anesthésie. Ces valeurs ont été comparées à celles obtenues a partir d'un groupe-témoin ( $n=20)$ dont l'âge s'échelonnait de sept mois à neuff $(3.3 \pm 2.7)$ ans. Une valeur de $\mathrm{pH}$ gastrique de plus de 2.5 a été mesurée chez 23 des 25 patients qui ont résu du citrate de sodium. Seulement deux des patients dans le groupetémoin avaient un $p H$ gasirique de plus de 2.5, $p<0.001$, test Fisher exact. Un seul enfant a refusé de prendre le médicamentt. Il semble que l'adminisiration de citrate de sodium soit une méthode efficace pour augmenter le $\mathrm{pH}$ du contenu gastrique chez les patients pédiatriques. 